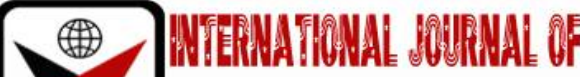

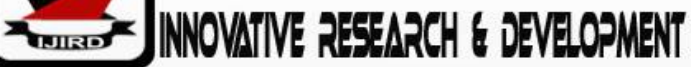

ISSN 2278-0211 (Online)

\section{Implementation of Shallow Seismic Refraction for Geotechnical Parameters Determination at New Cairo Industrial City, Egypt}

\author{
Nada Mohammed Hamdy Mashaal \\ Ph.D. Student, Department of Geology Department, Damietta University, Egypt \\ Gad El Qady \\ Head, Department of National Research Institute of Astronomy and Geophysics, \\ National Research Institute of Astronomy and Geophysics, Egypt \\ Dr. Mohammed Ahmed Omran Wadi \\ Professor, Department of Geology Department, Damietta University, Egypt
}

\begin{abstract}
:
The Egyptian government is involved in establishing many industrial and urban zones on the borders of the capital and governorates, especially in the new cities. The study area is the proposed site for the establishment of the industrial zone of the city of New Cairo, $25 \mathrm{~km}$ from the old capital and is considered one of the most promising industrial zones in Egypt. The study was mainly conducted to map the subsurface geological conditions in the region, as well as to interpret the data in terms of the geotechnical properties of the underlying rock material. The study included seismic refraction survey obtained using forty-five (45) profiles to cover the study area.

Main findings, which can be deduced from the examination of different seismic records along different seismic shapes in the study area, the interpreted geophysical cross-sections elucidate a three-layered model. When converting Geoseismic layers of velocity values into three litho logical layers, the surface layer consists of clay (a mixture of soil, clay and gravel), the second layer consists of Marley limestone layer, and the third layer is hard limestone.

Dynamic geotechnical parameters of the base layers were detected by the seismic refraction method for the use of P-wave and SH-wave velocities in the study area. This study proposed a classification of the basic rock materials in the area investigated for engineering purposes based on all the criteria which calculated to three areas (high, moderate and low competent material zones) with different in its suitability to engineering purposes.
\end{abstract}

Keyword: Shallow seismic refraction, geotechnical parameters, new Cairo industrial city, egypt

\section{Introduction}

Industrial cities are considered to be places where study of its soil properties is neglected. Most urban planners think that the industrial cities do not need these studies because of the less load and height in the industrial buildings, compared with the human housing. The industrial city in New Cairo is one of the industrial cities that have increased demand by investors (NUCA, 2010 and TPH, 2014).

This study attempts to complete the lack of geotechnical information of the study area, because of its economic importance and the persistent increased number of workers at this area.

The dynamic elastic moduli can be calculated by measuring the velocity of the foundation. Cyclic dynamic loading makes extra load that is supplemented to the construction load. The overload of concrete material exceeds the maximum bearing capacity of the rock material. Soil efficiency measures are insufficient to assess the basis of the machine's location in the whole quiet and earthquake zone (Yousry, 2010).

The soil's mechanical characteristics depend on the elastic characteristics of the rock materials, which can be measured by the conventional methods or the geophysical measurements. For these reasons, a geophysical method was used to save time, effort and financial cost to survey the entire study area. Shallow seismic refraction method comes to light as a strong tool in calculating the geotechnical parameters from which their elastic deformation can be assessed for civil engineering projects (Adeep, 2010).

In this study, a shallow seismic refraction survey was conducted. The area was surveyed with 45 profiles to record Compression (P-wave) velocities and the same for recording ( $\mathrm{S}$-wave) velocities. Information of five drilled wells in the area were used (depth of drilling up to $30 \mathrm{~m}$ ) to compare the geological sequence and its connection with the measured wave velocities resulted from the survey. The measured seismic velocity values were used to obtain geotechnical characteristics in mathematical methods and to classify the study area according to such characteristics. 


\section{Location and Topography}

The industrial region of the New Cairo City is considered as one of the most promising industrial ones of Egypt. It far, easterly about $14 \mathrm{Km}$ from Cairo town and lies precisely between latitudes $29^{\circ} 56^{\prime} 45.68^{\prime \prime}$ and $29^{\circ} 58^{\prime} 47.53 \mathrm{~N}$ and longitudes $31^{\circ} 28^{\prime} 1.69^{\prime \prime}$ and $31^{\circ} 30^{\prime} 17.74^{\prime \prime}$ E covers a surface area of about $15 \mathrm{Km}^{2}$ (Fig. 1.).

It is clearly that the average ground elevation above sea level of the study area varying between95 $\mathrm{m}$ and about $260 \mathrm{~m}$ with gentle regional slope towards the Nile Valley, west direction. The relief around the study area shows a general decrease from relatively high values as at Gebel Elger in the north east (508 m.) to low values at the west towards the River Nile (88 m.) (Fig. 2.).

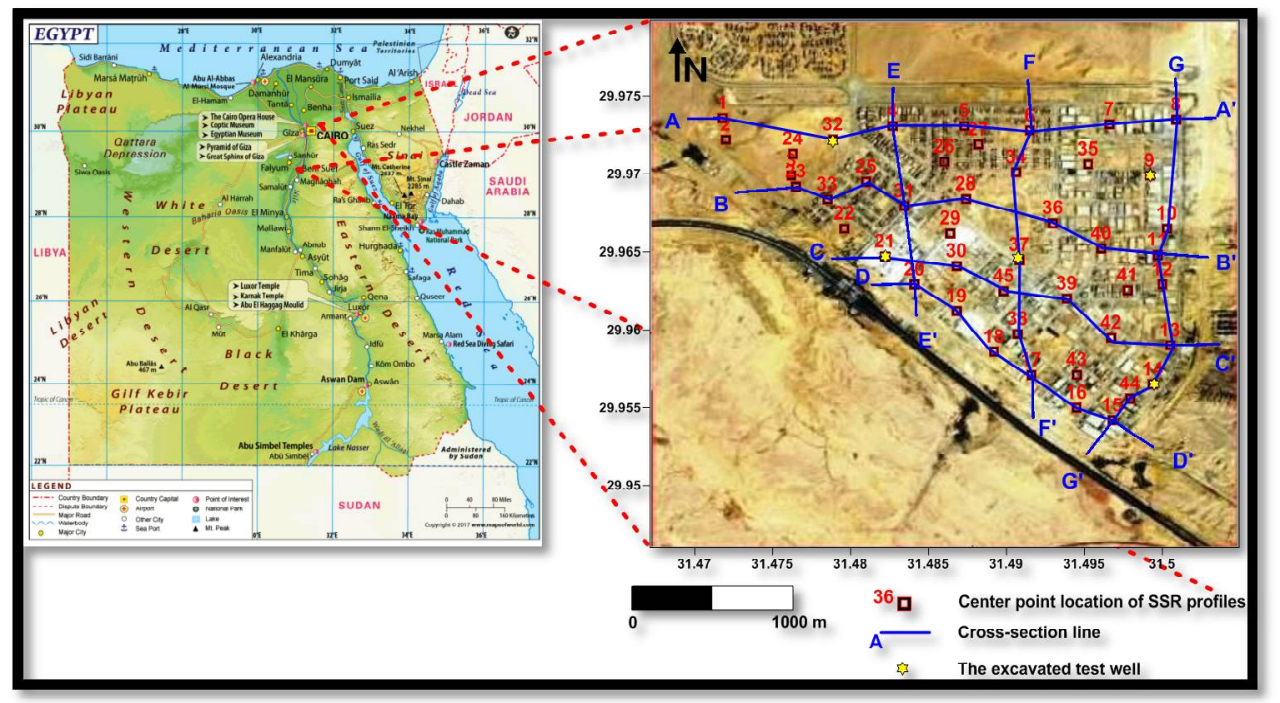

Figure 1: Location Map of the Study Area

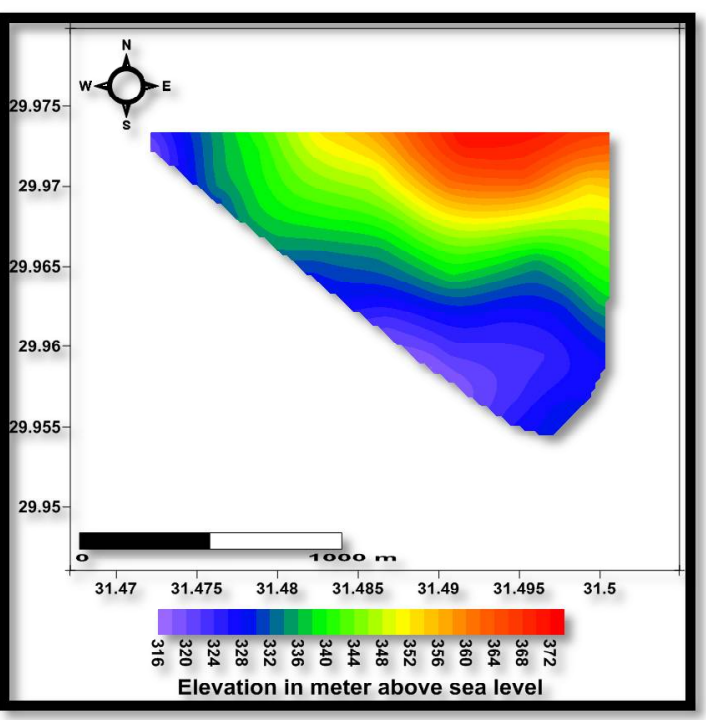

Figure 2: Topographic Contour Map of the Study Area (DEM 2018 Land-Stat ORION - ME)

\section{Geological Setting and Stratigraphy}

Generally; the stratigraphic succession in the study area ranges, in geological age, between the late-Early Eocene and the Oligocene. The Neogene sediments are exposedouter in the study area at Wadi Ghoweiba, Wadi Hagul, and to the north at Gebel Gharra, Gebel Iweibed, and Gebel Homeiyra. Quaternary sediments compose of alluvial terraces and cover the floors of wadis. The middle part of the Cairo-Suez district composes of a nearly parallel, high mountain edges trending in an E-Wand NW-SE directions with low-lands in the middle. The Middle Eocene rocks mostly assemble the mountains and high scarps disregarding both sides of the Qattamiya-Ain Sukhna road, whereas both the Upper Eocene and Oligocene sediments cap the low topographic areas as grabens. The Paleogene series in the study area, in stratigraphical view, consists of seven different rock units placed from base to top: Minia Fm., (TelMn), Gebel Hof Fm., (TemHo), Observatory Fm., (TemOb) coeval with Sannor Fm., (TemSn) in the eastern part of the study area, Qurn Fm., (TemQn), Maadi Fm., (TeuMd), and Gebel Ahmer (ToAh) Formation.

In general, the different phases of Eocene make up the first six units of lithography, while the Oligocene belongs to the last unit. A simplified geological map of the study area is drawn in figure 3.Beside the sedimentary rocks, some volcanic sheets are mostly basalts, it evidenced from numerous places along Cairo-Suez district (Bishay, 1961; Barakat and AbouKhadrah, 1971;Farag and Ismail, 1959;Cheethman, 1963;El Safori et al., 1997;Boukhary and Abdelmalik, 
1983;Osman, 2003;Strougo, 1985;Strougo and Boukhary, 1987;Shukri, 1953;Shukri and Akmal, 1953; Al Ahwani, 1982;Issawi et al., 2009). They were observed at Gebel Abu Treifiya, surrounding it from all sides excluding the northern face and also noted to the south of Gebel Umm Reheiat along the Qattamiya-Ain Sukhna road, comprises well-known hillocks (Guiraud, 1986; Guiraud and Bellion, 1995;Mckenzie et al., 1970; Le Pichon and Francheteau, 1978; Cochran, 1983; Girdler and Southren, 1987; Hempton, 1987; Joffe and Garfunkel, 1987; Steckler et al., 1988; Coleman, 1993; Khalil and McClay, 2001;Bignot and Strougo, 2002;Issawi and Osman, 2002; Bosworthetal., 2005;Tueckmantel et al., 2010;Haggag, 1991;Cheethman, 1963;El Safori et al., 1997;Patton et al., 1994). Basalt extrusion was the result of rejuvenation of the normal faults in E-Wand NW-SE direction for the period of late Oligocene and Early Miocene (Said 1962). These basalts were given out by (Meneisy and Abdel Aal, 1984) using K/Ar method, to the late Oligocene - early Miocene (Aquitanian; 22 \pm 2 Ma.).

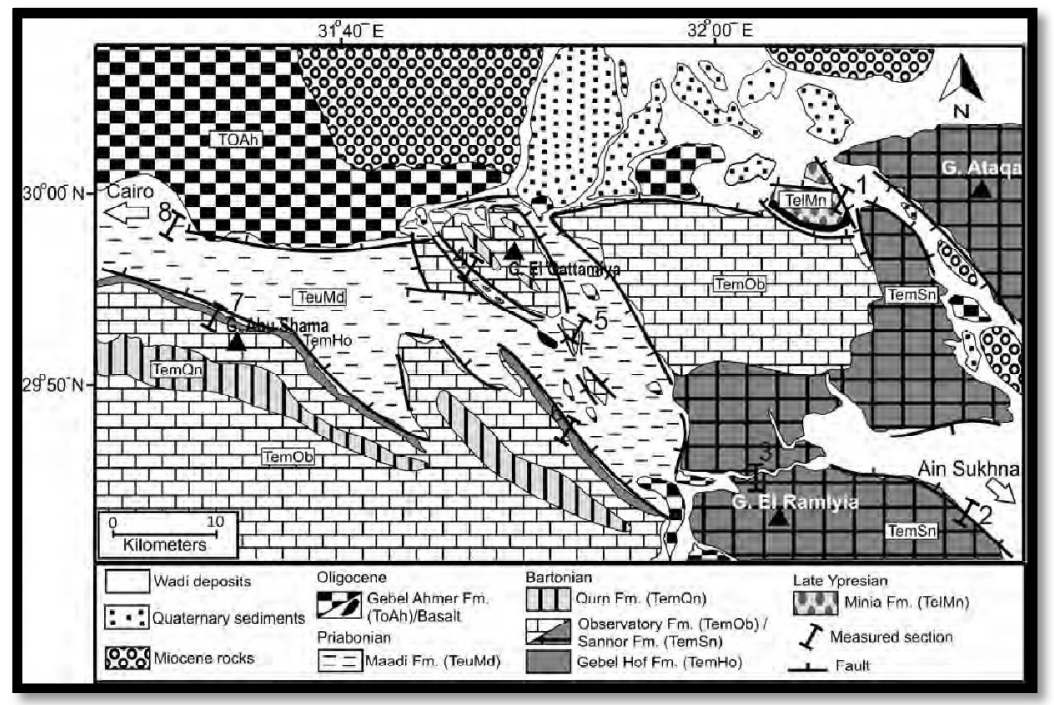

Figure 3: Geologicmap of the Studied Area (Modified From Said 1962). Map Labels: T Tertiary, E Eocene, L Lower, M Middle, U Upper, O Oligocene, Mn Minia, Ho Gebel Hof, Ob Observatory, Qnqurn, Sn Sannor, Md Maadi, And Ah Gebel Ahmer

\section{Materials and Methods}

The seismic method is the famous method that has been widely used particularly in civil engineering to measure the depth to bedrock in connection with the construction of large building, dams, highways and harbor survey (Valderrama, et al., 1996). Seismic refraction method is the most widely applied as a reconnaissance tool in newly explored areas, especially in engineering project. It mostly used in the mapping of the layers at shallow depth, layer thicknesses and some data about lithology can be obtained (Telford, et al., 1990). Seismic refraction manner used to evaluate the necessary parameters for constructions, or to solve the problems related to the geologic nature of sub-layers, mining works, and the environmental conditions overcame in the site. (Sharma, 1974)

Seismic exploration includes creation of artificial seismic waves and the recording of the arrival times of such waves from the origin to the sequences of geophones. In seismic prospecting, the motion of the earth surface generated by energy sources is shown in a seismic record. The motion is commonly recorded using instrumental system includes (geophone, amplifier, digital recorder, and units for monitoring. Conductance of the survey includes different spread system of geophones (Badley, 1985and Slotboom, et al., 1996).

The mark area of the New Cairo industrial area has been surveyed in January, 2019. All of 90shots of seismic are distributed along (45) seismic refraction profiles. The all seismic profiles are aligned in N-S direction. This study has a maximum length of each profile is $240 \mathrm{~m}$ with $5 \mathrm{~m}$ geophone spacing and the geophones and shot pint are in-line spread type. The survey is conducted using three different relative positions of the shoot point. In the first arrangement (Normal arrangement) the shot point is places $5 \mathrm{~m}$ from the first geophone, in the second arrangement (Middle arrangement) the shot point is places in the intermediate point near the geophone number 24, and in the third arrangement (Reverse arrangement) the shot point is places $5 \mathrm{~m}$ from the last geophone.

The field equipment, which used in seismic refraction survey include as the following:

- The vibrations generator system is used to generate P and S-waves to erases it within the earth as a source of energy in this study.

- For picking up the particles motion, which produced from the seismic wave's arrivals at the ground surface, good sensitive geophones were used that converts the mechanical ground motion to electrical signal with voltage amplitude proportional to the received energy.

- Two arrays are used to distribute the geophones and stabilize them in the topsoil for measurement area, the vertical geophones are used to detect the $\mathrm{P}$ waves, and the horizontal geophones are used to detect the $\mathrm{S}$ waves.

- The electric signals, which are converted from the motion of the ground that sourced by the vibration generator and detected by geophones, are transmitted through wires to the recording system. The system includes amplifying-filtering process of the recorded signal. The recording system is called seismograph "GEOMETRICS, 
SMARTSEIS". It is 48 channels signal enhancement seismograph powered with $12 \mathrm{~V}$ DC Battery with operating temperature ranges between $0^{\circ} \mathrm{C}$ and $45^{\circ} \mathrm{C}$.

- In order to avoid losing the wave force that may arise from the blind layer in some cases we use the force of the vibration generator. The recording system used has a low-pass filter, which is placed in front of the analog digital conversion circuit, with a response of 7-10 MHz. Some special field preparations have been made in the generation and recording of the $\mathrm{S}$ wave in order to avoid noise (Fig. 4.), First, it included switching the vibration generator to the $S$-wave mode for "45-degree pulse" at the point of picking point. This makes them spread in the "air" with very weak conductivity of the waves and this will delay and weaken the P waves. From the above it can be concluded that most waves reaching and detecting by geophones will be S-waves. In another numerical way, $\mathrm{S}$ waves are lower in values than P waves, because of this they can be digitally separated by a software program.

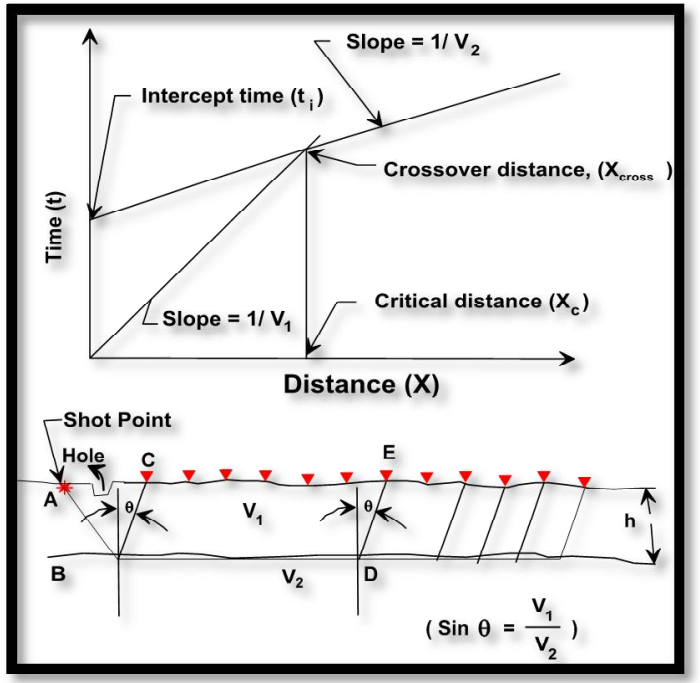

Figure 4: Velocity Estimation Using the Slope Method Calculation with Shot-Point and Geophones Array in Field (After Basheer, Et Al., 2013)

\section{Data Processing and Results}

The computer software (SIP version 6.23, Seisimager version 3.3 and winsism ${ }^{\mathrm{TM}}$ version 10) programs have been used to estimate:

- The parameters of the time-distance curve (the first time of seismic signals breaks and the geophones offset distance). This curve is obtained by plotting the first time of breaks (the arrival times can be picked also from the seismograms) against the geophones offset distance, the velocity of each segment of T-X curve is defined from the slope of the straight lines, which fits the segment.

- The different layer parameters as (thickness, depths, and the different velocities under each geophone).

- The Geoseismic crosses sections along each recorded profile in the study area.

- The seismic data have been also used to get the different geotechnical characteristics of the foundation materials of the subsurface stratums.

\subsection{Geo-Seismic Layers}

Depending on the vertical distribution of the $\mathrm{P}$ and $\mathrm{S}$ waves and comparing them to the excavated test wells in the region(Fig. 1.), it can be seen that the area consists of three geo-seismic layers. Figure (5) shows the Time-Distance curve and Geo-seismic cross-section along profile No. 14 as an example for P and S waves. The surface layer has P-wave velocity ranged from $592 \mathrm{~m} / \mathrm{sec}$ to $693 \mathrm{~m} / \mathrm{sec}$; while the S-wave velocity of this layer ranges between $318 \mathrm{~m} / \mathrm{sec}$ to $369 \mathrm{~m} / \mathrm{sec}$. The surface layer has thickness ranges between about $8.00 \mathrm{~m}$ and $17.24 \mathrm{~m}$.

Its lithology can refer to mixture of sand, gravel, and wadi deposits. The second layer's P-waves velocity ranges between $1138 \mathrm{~m} / \mathrm{sec}$ and $1302 \mathrm{~m} / \mathrm{sec}$ and the S-wave velocity of this layer is ranged from 592to674 m/sec. The depth to this layer varies from $309 \mathrm{~m}$. to $353.76 \mathrm{~m}$. and its thickness ranges between about $14.00 \mathrm{~m}$ and $25.00 \mathrm{~m}$. This layer may be corresponding to lithology of sandy to argillaceous-limestone. The third layer shows P-wave velocity of about $1703 \mathrm{~m} / \mathrm{sec}$ to $1897 \mathrm{~m} / \mathrm{sec}$. The depth to this layer ranges between $295.43 \mathrm{~m}$ to $328.76 \mathrm{~m}$. This layer may correspond to lithology of hard limestone.

Figures (6 and 7) shows the vertical distribution of $\mathrm{P}$ and $\mathrm{S}$ waves along profiles A-A', B-B', C-C', and D-D' from east to west, and E-E', F-F', and G-G' from North to south. The horizontal distributions of $P$ and $S$ waves in the surface, the second and the third layers have been illustrated in Figures (8 and 9). 


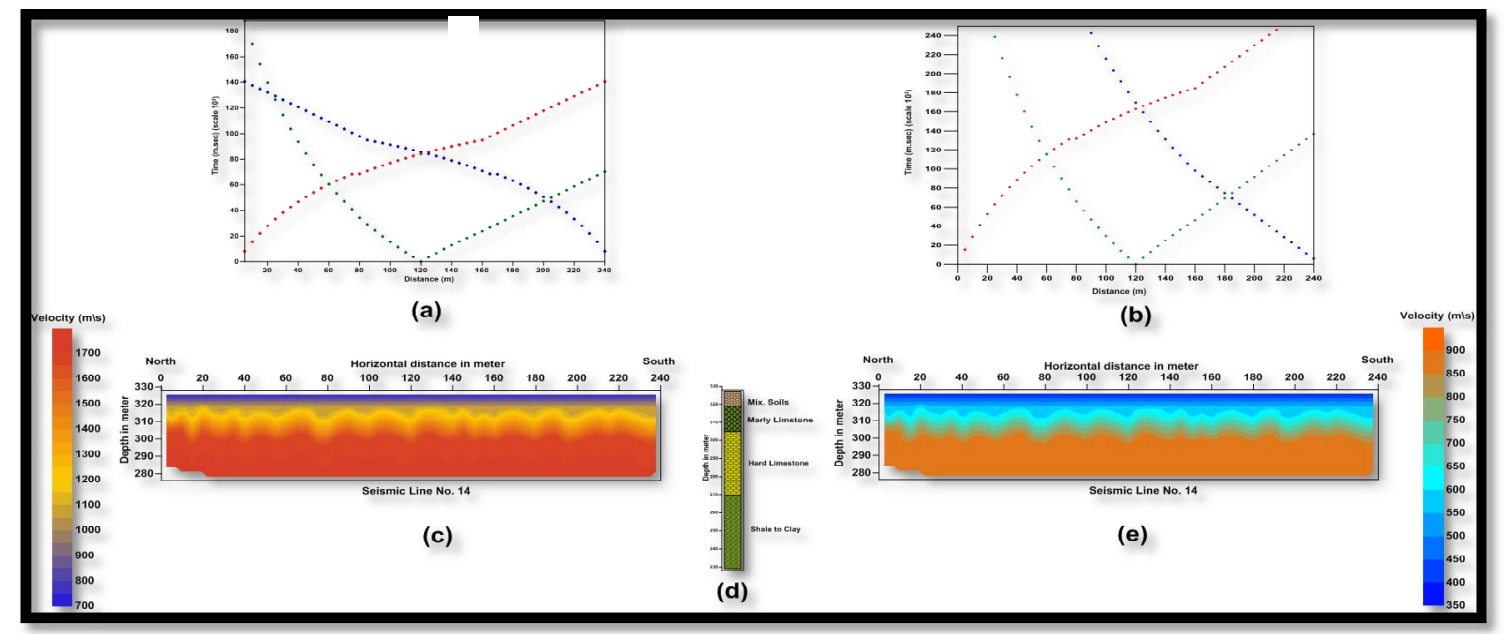

Figure 5: A) Time-Distance Curves of Vp Along Profile "14" B) Time-Distance Curves of Vs Along Profile "14" C) Vertical Distribution of Vp Velocity Of Profile "14" D) Core Sample on the Site of Profile "14" E) Vertical Distribution of Vs Velocity of Profile "14"

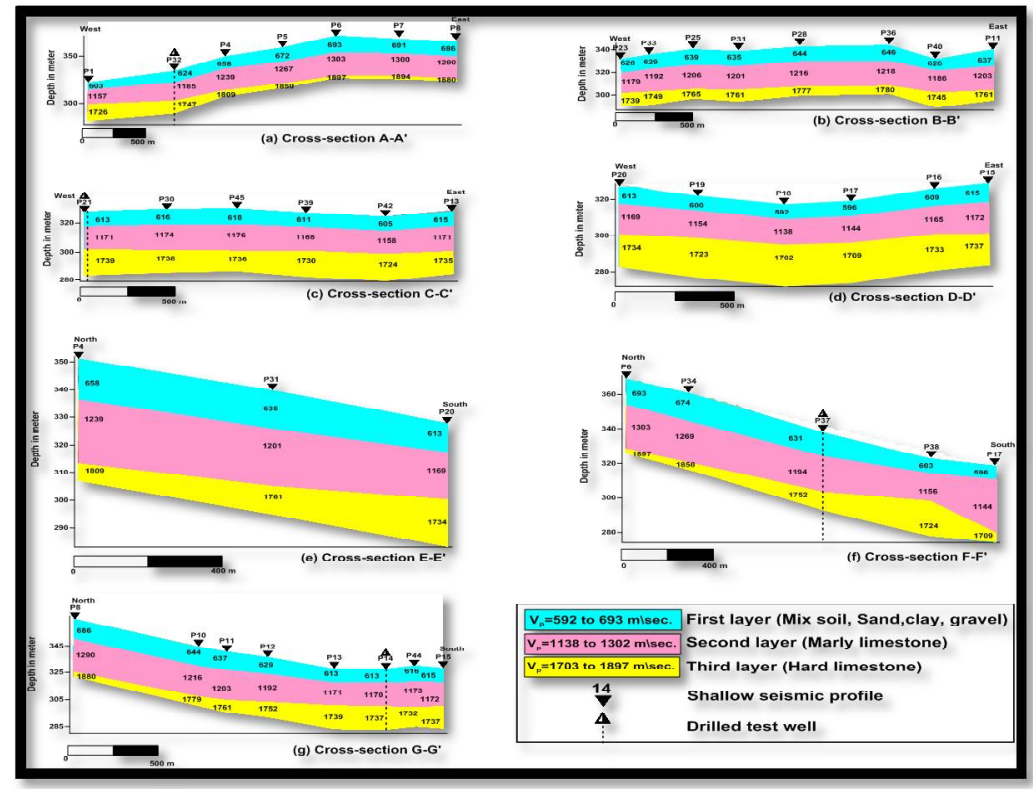

Figure 6: Geoseismic Cross Section of $V_{p}$ Along Profile $(A-A),\left(B-B^{\prime}\right)$, $\left(C-C^{\prime}\right),\left(D-D^{\prime}\right),\left(E-E^{\prime}\right),\left(F-F^{\prime}\right)$, and $\left(G-G^{\prime}\right)$

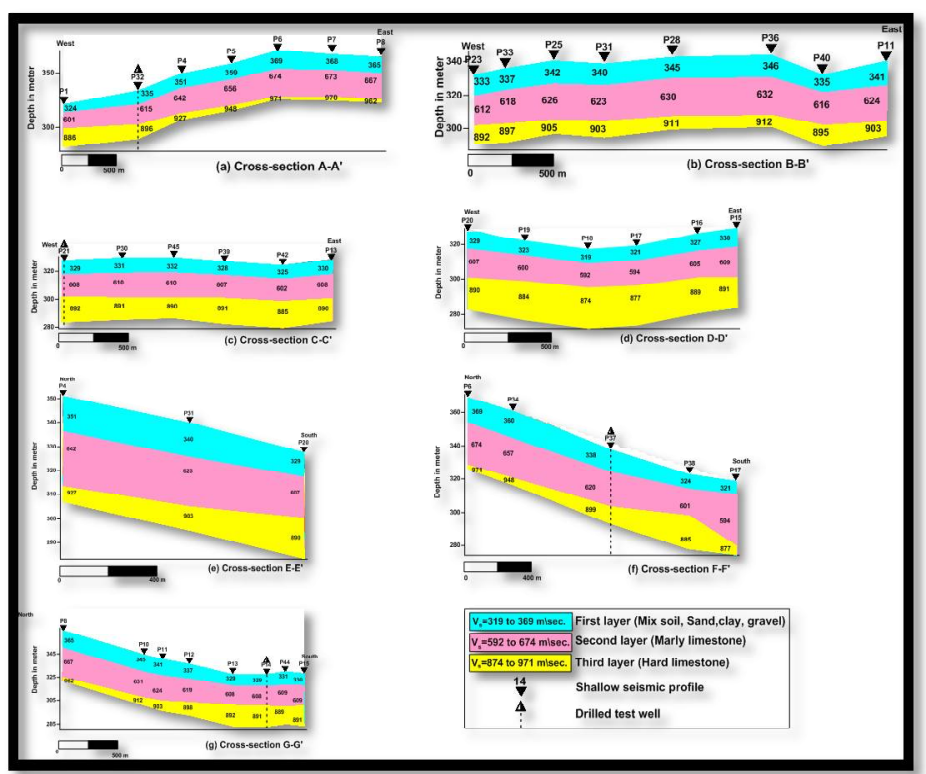

Figure 7: Geoseismic Cross Section of $V_{s}$ along Profile $(A-A)$, $\left(B-B^{\prime}\right),\left(C-C^{\prime}\right),\left(D-D^{\prime}\right),\left(E-E^{\prime}\right),\left(F-F^{\prime}\right)$, and $\left(G-G^{\prime}\right)$ 


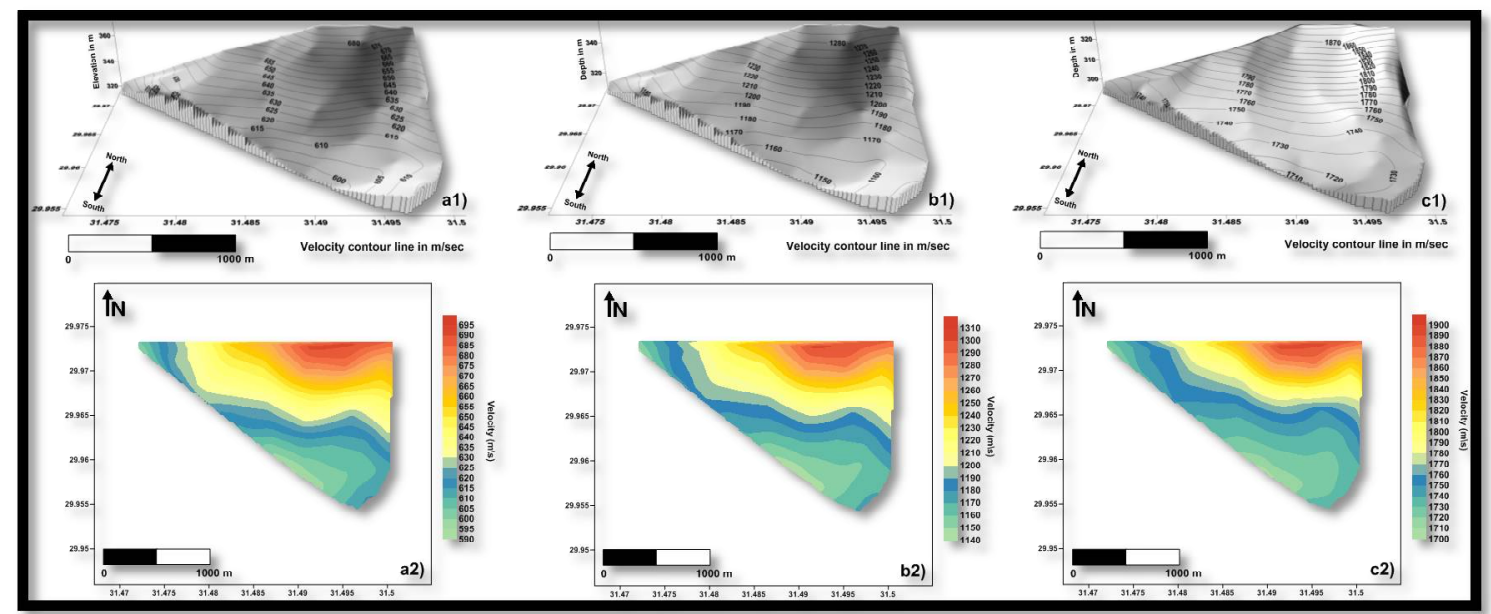

Figure 8:The Distribution of P-Waves Velocity, A1) A 3D Map Showing the Distribution of P-Wave Velocity in the First Layer in the Mark Area, A2) 2D Map Showing the Distribution of P-Wave Velocity in the First Layer in the Mark Area B1) A 3D Map Showing the Distribution of P-Wave Velocity in the Second Layer in the Mark Area, B2) 2D Map Showing the Distribution of PWave Velocity in the Second Layer in the Mark Area. C1) A 3D Map Showing the Distribution of P-Wave Velocity in the Third

Layer in the Mark Area, C2) 2D Map Showing the Distribution of P-Wave Velocity in the Third Layer in the Mark Area

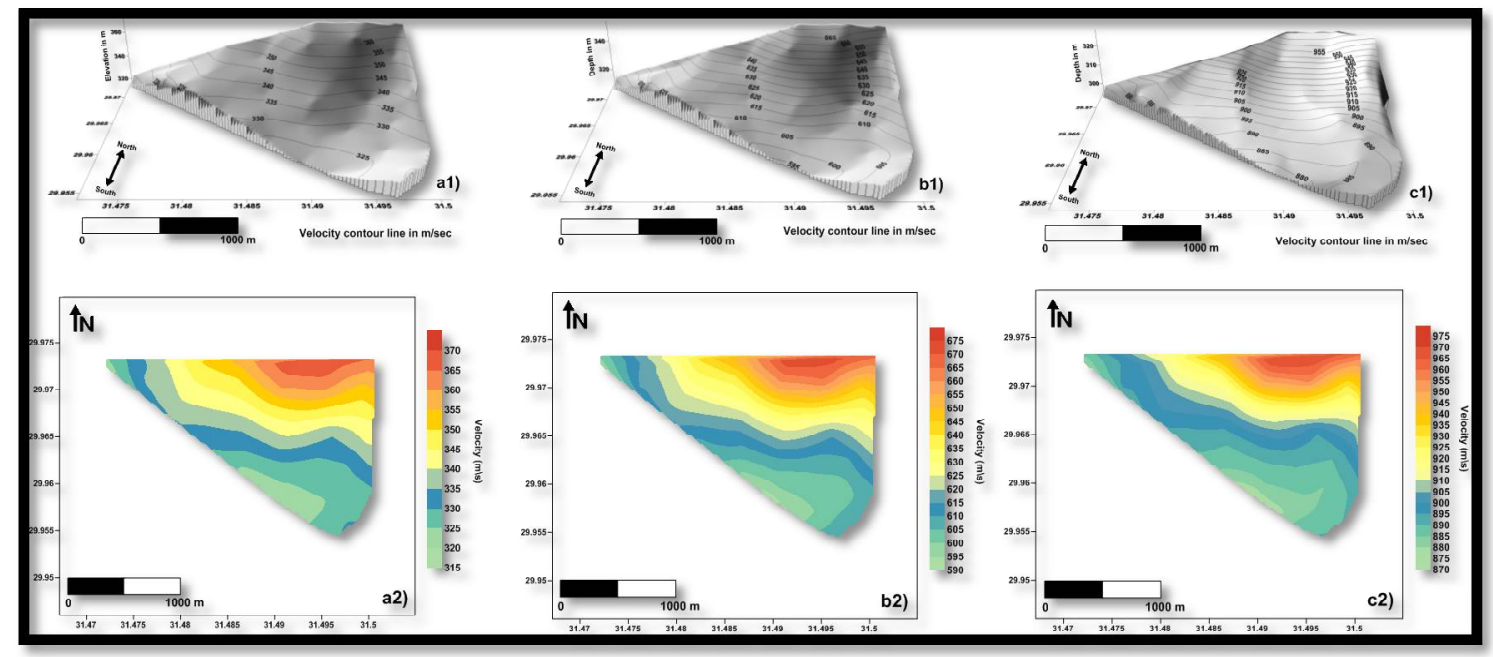

Figure 9:The Distribution of S-Wave Velocity, A1) A 3D Map Showing the Distribution of S-Wave Velocity in the First Layer in the Mark Area, A2) 2D Map Showing the Distribution of S-Wave Velocity in the First Layer in the Mark Area B1) A 3D Map Showing the Distribution of S-Wave Velocity in the Second Layer in the Mark Area, B2) 2D Map Showing the Distribution of SWave Velocity in the Second Layer in the Mark Area. C1) A 3D Map Showing the Distribution of S-Wave Velocity in the Third Layer in the Mark Area, C2) 2D Map Showing the Distribution of S-Wave Velocity in the Third Layer in the Mark Area

\subsection{Geotechnical Characterizations of the Foundation Material}

The seismic method has become a leading application in the calculation of elastic modules that can estimate the elastic deformation in the field of civil engineering. (Harden and Drnevich 1972; David and Taylor Smith 1979; Stumpel et.al 1984; Aoki and Matsukura, 2008; Andersen and Schjetne, 2013).The specified elastic dynamic coefficient is calculated by the measurements of the speed of the base rock described in the natural (earthquakes) and also in the artificial (machine) cyclic dynamic. This coefficient uses to estimate the additional load on the load of the building, and then it can be known how much load can exceed the ultimate bearing capacity of subsurface rock materials (Bowles 1984). Unfortunately, the samples taken and analyzed to determine soil competence scales do not represent the whole area of the study and are not sufficient to evaluate them both in the quiet area and those arising from the earthquake.

In building engineering, soil is defined as "the material covering the underlying layer produced by rock weathering". Soil is the non-cohesive material of earth's crust rocks, used for construction on it or as building materials. The mechanical properties of the soil rely on the material elastic properties, which can be measured by usual engineering methods or from field geophysical measurements (Sjorgren et.al 1979; Dutta 1984; Abd Elrhman et.al., 1991\&1992; Azimian, et al., 2014; ASTM, 2015).

This study makes a view on the foundation rock in the investigated region (the industrial region of the New Cairo City) using the shallow seismic refraction measurements (Compressional and Shear wave's velocity).Geotechnical moduli, parameters, and properties were calculated using mathematical equations and their relation to the measured velocities in each layer (table 1.). 


\begin{tabular}{|c|c|c|c|c|c|c|c|c|c|}
\hline \multirow{2}{*}{\multicolumn{2}{|c|}{$\begin{array}{l}\text { Mechanical } \\
\text { Properties }\end{array}$}} & \multirow{3}{*}{$\begin{array}{c}\text { Used equation } \\
\\
\sigma=1- \\
2\left(\mathrm{Vs}^{2} / \mathrm{Vp}^{2}\right) / 2[1- \\
\left.\left(\mathrm{Vs}^{2} / \mathrm{Vp}^{2}\right)\right] \\
\end{array}$} & \multirow{3}{*}{\begin{tabular}{|c|} 
after \\
\\
Sheriff \\
1991
\end{tabular}} & \multicolumn{2}{|c|}{$\begin{array}{l}\text { Surface } \\
\text { layer }\end{array}$} & \multicolumn{2}{|c|}{ Second Layer } & \multicolumn{2}{|c|}{ Third Layer } \\
\hline & & & & \multirow{2}{*}{$\begin{array}{l}\text { From } \\
0.296\end{array}$} & \multirow{2}{*}{$\frac{\text { To }}{0.302}$} & \multirow{2}{*}{$\begin{array}{c}\text { From } \\
0.3148\end{array}$} & \multirow{2}{*}{$\begin{array}{c}\text { To } \\
0.3176\end{array}$} & \multirow{2}{*}{$\begin{array}{c}\text { From } \\
0.3211\end{array}$} & \multirow{2}{*}{$\begin{array}{c}\text { To } \\
0.3226\end{array}$} \\
\hline $\begin{array}{l}\text { Elastic } \\
\text { moduli }\end{array}$ & $\begin{array}{l}\text { Poisson's } \\
\text { ratio }\end{array}$ & & & & & & & & \\
\hline & $\begin{array}{l}\text { Kinetic } \\
\text { rigidity } \\
\text { modulus }\end{array}$ & $\begin{array}{c}\rho=1.62+0.00021 V_{p} \\
\mu=\rho . V s^{2} . g\end{array}$ & $\begin{array}{c}\text { Imai's } \\
\text { law\& } \\
\text { Gardener } \\
1939\end{array}$ & 165 & 230 & 700 & 920 & 2100 & 2650 \\
\hline & $\begin{array}{l}\text { Kinetic } \\
\text { young's } \\
\text { modulus }\end{array}$ & $\mathrm{E}=2 \cdot \mu \cdot(1+\sigma)$ & $\begin{array}{c}\text { Sheriff } \\
1991\end{array}$ & 430 & 600 & 1800 & 2450 & 5500 & 7000 \\
\hline & $\begin{array}{l}\text { Kinetic bulk } \\
\text { modulus }\end{array}$ & $\begin{array}{c}\mathrm{K}=\mathrm{E} / 3(1-2 \sigma)=\rho . \\
{\left[\mathrm{Vp}^{2}-(3 / 4) \mathrm{Vs}^{2}\right]}\end{array}$ & $\begin{array}{c}\text { Sheriff } \\
1991\end{array}$ & 350 & 510 & 1650 & 2250 & 5100 & 6600 \\
\hline & $\mathrm{N}$-value & $\mathrm{Vs}=89.9 \mathrm{~N}^{0.341}$ & $\begin{array}{c}\text { Imai's } \\
1976 \\
\& \\
\text { Bowles } \\
1984\end{array}$ & 41 & 64 & 250 & 380 & 780 & 1080 \\
\hline \multirow[t]{4}{*}{$\begin{array}{c}\text { Material } \\
\text { competence }\end{array}$} & $\begin{array}{l}\text { Material } \\
\text { index }\end{array}$ & $\begin{array}{c}v=(\mu-\lambda) /(\mu-\lambda) \\
=1-4 \sigma\end{array}$ & $\begin{array}{c}\text { Abd } \\
\text { Elrhman } \\
1989 \\
\end{array}$ & $\begin{array}{c}- \\
0.208\end{array}$ & $\begin{array}{c}- \\
0.184\end{array}$ & $\begin{array}{c}- \\
0.2695\end{array}$ & -0.26 & -0.29 & -0.284 \\
\hline & $\begin{array}{c}\text { Concentration } \\
\text { index }\end{array}$ & $\begin{array}{c}\mathrm{Ci}=[3- \\
\left.4\left(\mathrm{Vs}^{2} / \mathrm{Vp}^{2}\right)\right] /[1- \\
\left.2\left(\mathrm{Vs}^{2} / \mathrm{Vp}^{2}\right)\right]\end{array}$ & $\begin{array}{c}\text { Abd } \\
\text { Elrhman } \\
1991\end{array}$ & 4.31 & 4.385 & 4.152 & 4.179 & 4.101 & 4.115 \\
\hline & Stress ratio & $\mathrm{Si}=1-2\left(\mathrm{Vs}^{2} / \mathrm{Vp}^{2}\right)$ & $\begin{array}{c}\text { Tatham } \\
\text { and Krug } \\
1986\end{array}$ & 0.42 & 0.434 & 0.4595 & 0.4655 & 0.473 & 0.4762 \\
\hline & $\begin{array}{l}\text { Density } \\
\text { gradient }\end{array}$ & $\begin{array}{c}\mathrm{Di}=[1-(4 / 3)- \\
\left.\left(\mathrm{Vs}^{2} / \mathrm{Vp}^{2}\right)\right]^{-1}\end{array}$ & $\begin{array}{l}\text { Stumpel } \\
\text { et.al } \\
1984\end{array}$ & $\begin{array}{c}3.3 \mathrm{X} \\
10^{-6}\end{array}$ & $\begin{array}{c}4.7 X \\
10^{-6}\end{array}$ & $\begin{array}{c}9 \times 10^{-} \\
7\end{array}$ & $\begin{array}{c}1.22 \mathrm{X} \\
10^{-6}\end{array}$ & $\begin{array}{c}4.25 X \\
10^{-7}\end{array}$ & $\begin{array}{c}5.35 X \\
10^{-7}\end{array}$ \\
\hline \multirow{2}{*}{$\begin{array}{c}\text { Foundation } \\
\text { material } \\
\text { bearing } \\
\text { capacity }\end{array}$} & $\begin{array}{l}\text { Ultimate } \\
\text { bearing } \\
\text { capacity }\end{array}$ & $\mathrm{Q}_{\mathrm{ult}}=10^{2.932(\log V s-}$ & $\begin{array}{c}\text { parry's } \\
\text { formula } \\
(1977\end{array}$ & 1200 & 1950 & 7400 & 11400 & 32500 & 33000 \\
\hline & $\begin{array}{l}\text { Allowable } \\
\text { bearing } \\
\text { capacity }\end{array}$ & $\begin{array}{c}\text { For cohesive soil } \\
\text { Log } \mathrm{Qa}=2.932 \\
\text { Log Vs }-4.553 \\
\text { For cohessionless } \\
\text { soil } \\
\text { Log } \mathrm{Qa}=2.932 \\
\text { Log Vs }-4.729\end{array}$ & $\begin{array}{l}\text { Abd } \\
\text { Elrhman } \\
\text { et.al., } \\
1991\end{array}$ & 410 & 640 & 2500 & 3800 & 7800 & 11000 \\
\hline
\end{tabular}

Table 1: Summarizing All the Estimated Elastic Moduli, Material Competence, and Bearing Capacity of the Foundation Materials

\section{Conclusion and Recommendation}

The study area is the suggested location for establishing the industrial region of the New Cairo City which is considered as one of the most promising industrial ones of Egypt. The study has been performed principally to elucidate the subsurface geological conditions in the area, also an interpretation of the data in terms of the geotechnical characteristics of the foundation rock materials. The study involves carrying out seismic refraction data acquired using forty-five (45) profiles for each tool over the study area.

The main presumptions, which can be deduced from inspection of the different seismic records along the different seismic profiles in the study area and its vicinity as follow:

- The interpreted Geoseismic cross-sections suggest three-layer model.

- The Geoseismic layers were converted from the velocity's values into three lithologic layers as: 
- Surface layer: clay (mix soil of sand, clay and gravel)

- Second layer: Marley limestone layer

- Third layer: Hard limestone.

The dynamic geotechnical parameters of the foundation layers are revealed by seismic refraction method for utilizing the velocities of P-waves and SH-waves at the study area.

This study proposes a classification to foundation rock material in the investigated region for engineering purposes based on all the calculated moduli and parameters. This study divided to the following zones (Fig.10.):

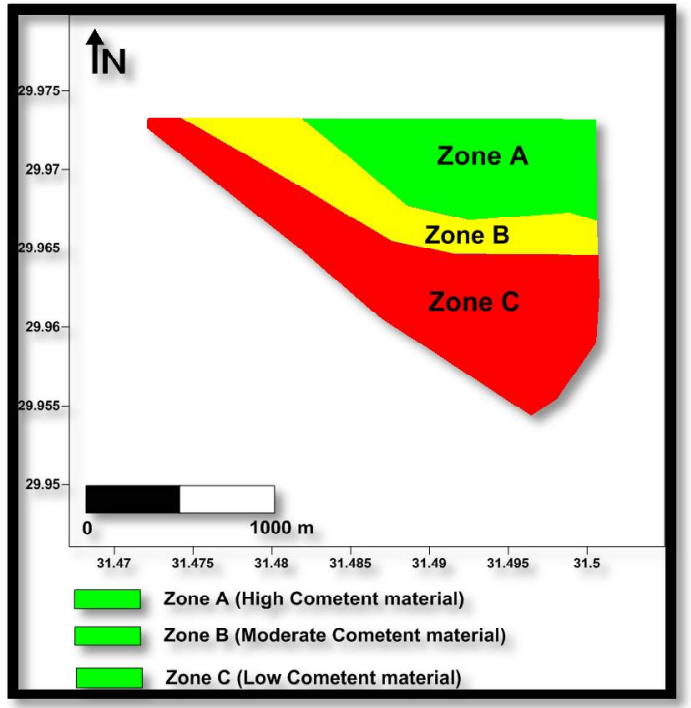

Figure 10: Classification of the Foundation Rock Material Quality for Engineering Purposes According to the Geotechnical Characteristics in the Investigated Region, the Industrial Region of the New Cairo City

\subsection{ZONE (A): (High Competent Material Zone)}

This zone covers the eastern and the northeastern corners and the small strip in the northern quarter of the investigated region. High competent materials characterize this zone suggesting suitability for any engineering purposes.

\subsection{ZONE (B): (Moderate Competent Material Zone)}

This zone covers the center part of the investigated region with some extent to the west. This zone consists of moderate competent materials which is suitable for limited construction purposes.

\subsection{ZONE (C): (Low Competent Material Zone)}

This zone covers the southeastern part of the investigated region with some extent to the southwest. This zone consists of low competent materials not suitable for limited construction purposes. This zone is suggesting non-suitability for heavy engineering purposes that must be keeping away from any constructions or loudness and watery activities.

Finally, the study delineates clearly the main structural trends in the study area. These trends should be carefully avoided when the planer and the officials plan the city and its roads. This shininess will protect roads to be broken by any overload produce from cars and vans or sudden earthquakes. The findings of the study show the nature and shape of the boundaries of the basic materials that compose the subsurface layers and their geotechnical properties. It is clear that these results are reasonable and acceptable and have a significant impact in the field of civil engineering and other purposes, achieving the main objectives of the study.

\section{References}

i. Abd Elrahman, M.M.(1991). Rock material competence assessed by seismic measurements with emphasis on soil competence scales and their applications in some urban areas in Yemen, EGS. Proc.of the ${ }^{\text {th }}$ Ann. Meet. 9; PP. 205230.

ii. Abd Elrahman, M., Setto, I., and Elwerr,(1992).Inferring mechanical properties of the foundation materials at the $2^{\text {nd }}$ industrial zone, Sadat City, from Geophysical measurement, EGS. Proc. Of the 10th. Ann. Meet. 10, PP.50-62.

iii. Adeep, S. (2000). Housing Economics under Market Mechanisms, Cairo University - Faculty of Engineering, 2000.

iv. Alhwani, M.M.(1982). Geological and sedimentological studies of Gebel Shabrawet area, Suez Canal district, Egypt. Ann GeolSurv Egypt, 12:305-381.

v. Andersen, K.H., and Schjetne, K. (2013). "Database of Friction Angles of Sand and Consolidation Characteristics of Sand, Silt, and Clay," Journal of Geotechnical and Geo-environmental Engineering, ASCE, Vol. 139, No. 7, pp. 11401155. DOI: 10.1061/(ASCE)GT.1943-5606.0000839.

vi. Aoki, H., and Matsukura, Y. (2008). "Estimating the unconfined compressive strength of intact rocks from Equotip hardness," Bulletin of Engineering Geology and the Environment, Springer-Verlag, Vol. 67, No. 1, pp. 23-29. DOI: 10.1007/s10064-007-0116-z 
vii. ASTM D2573, (2015). Standard Test Method for Field Vane Shear Test in Saturated Fine-Grained Soils, ASTM International. DOI: 10.1520/D2573_D2573M-15

viii. Azimian, A., Ajalloeian, R., and Fatehi, L. (2014). "An Empirical Correlation of Uniaxial Compressive Strength with P-Wave Velocity and Point Load Strength Index on Marly Rocks Using Statistical Method," Geotechnical and Geological Engineering, Vol. 32, No. 1, pp. 205-214. DOI: 10.1007/s10706-013-9703-x

ix. Badley, M.E. (1985). Practical seismic interpretation: Boston, International Human Resources Development Corp., $266 \mathrm{p}$.

x. Basheer, A.A., Atya, M.A., Shokri, M., and Abu shady M.M. (2012). Application of ERT and SSR to detect the subsurface cave at 15th May City, Helwan, Egypt, NRIAG Journal of Astronomy and Geophysics (2012), 1, Available online 20 January 2013, pp. 23-32.

xi. Bignot, G., Strougo, A. 2002. Middle Eocene benthic for aminiferal assemblages from Eastern Egypt, as biochronological et peritethyanlagoonal indicators. Rev Micropaleontol 45(2):73-98.

xii. Bishay, Y. (1961). Biostratigraphic study of the Eocene in the Eastern Desert between Samalut and Assiut by the larger foraminifera. $3^{\text {rd }}$ Arab Petrol. Congr. Alex 2:7

xiii. $\quad$ Bosworth W., Huchon, P., McClay, K.(2005). The Red Sea and Gulf of Aden basins. J Afr Earth Sci 43:334-378.

xiv. Boukhary, M.A., Abdelmalik, W. (1983). Revision of the stratigraphy of the Eocene deposits in Egypt. N JbGeolPalaontol-MhStuttg 6:321- 337.

xv. Bowles, J.E. (1984). Physical and Geotechnical properties of soil. McGraw-Hill London, P. 477-480.

xvi. Cheethman, A., (1963). Late Eocene zoography of the Eastern Gulf Coast region. Mem Geol Soc Am 93:113.

xvii. Cochran, J.R.(1983). A model for development of the Red Sea. Am Assoc Pet Geol Bull 67:41-69.

xviii. Coleman, R.G.(1993). Geologic Evolution of the Red Sea. In: Oxford Monographs on Geology and Geophysics, v. 24. Oxford University Press, Oxford, 186 pp.

xix. David and Taylor Smith, (1979). Applications of $V_{p} \& V_{s}$ in Lithology. Geophysics; Cambridge University Press, New York,860.

xx. Dutta, N.P.(1984). Seismic refraction method to study the foundation rock of a dam. Geophysical Prospecting, 32. 1103-1110.

xxi. $\quad$ El Safori, Y.A., Zalat, A.A., Eweda, S.A., Maih, A.M. (1997). Eocene facies and bryozoans of the Qattamia area, Egypt. J Geol Egypt 41(2A):365-425.

xxii. Farag, I.M., and Ismail, M.M.(1959). A contribution to the structure of the area east of Helwan. Egypt. J Geol 3:7186.

xxiii. Gardener A.T.(1939). Physical and Geotechnical properties of soil. Geosci. Cambridge.P.401-422.

xxiv. GEOMETRIC SMARTSEIS system,[Computer Software] (2015). Geostuff, 1579 Lupine Lane Lincoln, California 95648 USA, user manuals and

applications,ftp://geom.geometrics.com/pub/seismic/Manuals/SmartSeisVersionC.pdf.

xxv. Girdler, R.W., and Southren, T.C.(1987). Structure and evolution of the northern Red Sea. Nature 330:716-721.

xxvi. Guiraud, R.(1986). Correlations entre les principauxevenmentsgeodynamiquesenregistres du Triasa'nosjours sur les marges alpine et atlantique de la plaque africaine. Rev. Fac., Sc., Marrakech Sect. Sci., Terre. No. Spec. 2 PICG UNESCO, v. 183, p. 313-338.

xxvii. Guiraud, R., and Bellion, Y.(1995). Late carboniferous to recent geodynamic evolution of the west Gondwaniancratonic Tethyan margins. In: Narin A (ed) The ocean basins and margins. Plenum, New York, pp 101124.

xxviii. Haggag, M.A.,(1991). Planktonic foraminiferal groups and zonation of Paleogene/Eocene of the South Galala and environs. Egypt J Geol 35(1-2):37-50.

xxix. Harden and Dranevich, (1972).Elastic Moduli Estimation for Civil Engineering; Cambridge University Press. 12-29.

xxx. Hempton, M.(1987). Constraints on Arabian plate motion and extensional history of the Red Sea. Tectonics 6:687705.

xxxi. Imai, (1975).The functions of seismic wave in ground material and its interpretations. Geophysics, vol. 40, PP. 746-798.

xxxii. Imai, (1976).The functions of seismic wave in ground material and its interpretations. Geophysics, vol. 41, PP. 745-797

xxxiii. Issawi, B., and Osman, R.(2002). Geological history of NE Egypt during the Paleozoic and Mesozoic as anticipated from lithofacies isopach maps. Geol. Arab World, Cairo Univ, 6th Int. Conf. II: 451-468.

xxxiv. Issawi, B., Francis, M., Youssef, A., Osman, R.(2009). The Phanerozoic of Egypt: a geodynamic approach. Geol. Surv. Egypt, Spec. Publ., no. 81, 589 p.

xxxv. Joffe, S., Garfunkel, Z.(1987). Plate kinematics of the circum Red Sea-a reevaluation. Tectonophysics 141:5-22

xxxvi. Khalil, S.M., and McClay, K.R.(2001). Tectonic evolution of the NW Red Sea- Gulf of Suez rift system. In Wilson, R.C.L., Whitmarsh, R.B., Taylor, B. \& Froitzheim, N. Non-volcanic rifting of continental margins: a comparison of evidence from land and sea. Special Publication, no. 187. Geological Society of London. p. 453-473.

xxxvii. Le Pichon, X., and Francheteau, J.(1978). A plate tectonic analysis of the Red Sea-Gulf of Aden area. Tectonophysics 46:369-406.

xxxviii. Mckenzie, D.P., Davies, D., and Molnar, P. (1970). Plate tectonics of the Red Sea and east Africa. Nature 226:243248.

xxxix. Meneisy and Abdel Aal, (1984). Meneisy MY, Abdel Aal AY (1984) Geochronology of phanerozoic volcanic rocks in Egypt. Bull Fac Sci Ain Shams Univ., Cairo, 25 (B24) 
xl. NUCA, (2010). The Official Publication of the New Cairo city, New Urban Communities Authority (NUCA), 2010.

xli. Osman, R.(2003). New findings in the Eocene stratigraphy of Gebel Ataqa-Northern Galala, North Eastern Desert, Egypt. J Sedi Egypt. 11:95-109

xlii. Parry, R.H.C., (1977). Estimating bearing capacity of sand from SPT values. JGED, ASCE, 103, Gt.9, P. 1013-1045.

xliii. Patton, T.L., Moustafa, A.R., Nelson, R.A., Abdine, S.A.(1994). Tectonic evolution and structural setting of the Suez Rift. In interior Rift Basins. (ed. S. M. London). American Association of Petroleum Memoir 59. p. 9-55.

xliv. Said, R. (1962). The geology of Egypt: Elsevier Pub.Contour., Amsterdam, New York, P. 336-338.

xlv. Seisimager Version 3.3.[Computer Software](2015).Jean-Luc Arsenault, USA, software

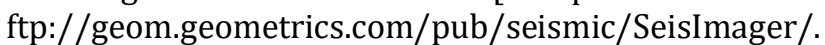

xlvi. Sharma, P.V.,(1974). Geophysical Methods in Geology. New York, Elsevier, 428 P.

xlvii. Sheriff, R.E.,(1991). Encyclopedic dictionary of exploration geophysics, 3th edition. Society of Exploration Geophysicists. PP??

xlviii. SIP Program Version 6.23.[Computer Software](2017).Seismic Interpretation program software, 15 South Street, Farnham Surrey, GU9 7QU United Kingdom. http://www.seismicimageprocessing.com

xlix. Sjogren, B., Ofsthus, A., and Sandberg, J.(1979). Seismic classification of rock mass qualities. Geophysical Prospecting, 1979, 27: P. 409-422.

l. Slotboom, R., T., Lawton, D., C., Spratt, D., A.(1996). Seismic interpretation of the triangle zone at Jumping Pond, Alberta: Bulletin of Canadian Petroleum Geology, vol. 44, p. 233-243.

li. Stumpel, H., Kahler, S., Meissner, R., and Milkerei, B.(1984).The use of seismic shear waves and compressional waves for lithological problems of shallow sediments: Geoph. Pros.,1984, 32, P.660-675.

lii. Tatham, R. H. and Krug,E.H.(1986). "Vp/Vs Interpretation" Ch. 5, p. 139-188, in: Developments in Geophysical Exploration Methods-6, A. A, Fitch, editor, Elsevier Applied Science Publishers, London, 264 p.

liii. Telford, W., M., Geldart, L., P., Sheriff, R., E.(1990). Applied Geophysics: Cambridge, Cambridge University Press, 770 p.

liv. TPH,(2014). Town Planning and Heritage: Principles Government, Town Planning Legislation, Heritage, Sustainability and Environmental Law, June 2014.

lv. Tueckmantel C, Fisher QJ, Knipe RJ, Lickorish H, Khalil S.M. (2010). Fault seal prediction of seismic-scale normal faults in porous sandstone: a case study from the eastern Gulf of Suez rift. Egypt, Mar Petrol Geol 27:334-350.

lvi. Valderrama, M., H., Nielsen, K., C., McMechan, G., A. (1996). Three-dimensional seismic interpretation from the triangle zone of the frontal Ouachita Mountains and Arkoma basin, Pittsburg County, Oklahoma: AAPG Bulletin, vol. 80, p. 1185-1202

lvii. Yousry, A.(2010). The Privatization of Urban Development in Cairo, Lessons Learned from the Development Experience of Al Rehab Gated Community, Faculty of Urban and Regional Planning, Cairo University, 2010.

lviii. Winsism ${ }^{\mathrm{TM}}$ version 16[Computer software] (2018).Winshttp://www.wgeosoft.ch/PDF/winsism_pub_us.html 